\title{
Social Democratic Reform Proposals and the Future of Capitalism
}

\author{
JAVED A. ANSARI and RAFIQUE A. KHAN
}

\section{INTRODUCTION}

This paper seeks to present an analysis of some issues raised in the debate on the future of capitalism by influential social democrats in recent years [Agleitta (1999); Habermas (1999); Rorty (1998)]. We begin with a brief description of capitalism's genesis, its characteristics and its need for moral legitimising and proceed to a slightly more extended discussion of capitalist processes at the beginning of the twenty-first century. The paper concludes with an assessment of initiatives proposed by social democratic thinkers such as Agleitta, Habermas and Rorty to strengthen capitalism and realise social democratic objectives-the universalisation of freedom and the promotion of liberal justices in rights centric societies.

\section{ORIGINS}

Contrary to the claims of neo and new classical economists e.g. [Hayek (1988)] capitalism has a history. Capitalist markets invariably emerge from non capitalist social formations - this is true even of the United States where for example Jaynes (1986, Chp. 15) has documented the legislative acts and policy measures adopted to create a labour market after the abolition of slavery in the decades after the civil war. The US government after 1865 enforced a legal political system that effectively disenfranchised the blacks, reduced their economic power and shaped the labour market. There was little "spontaneity" in the development of capital labour relations in the American south in the second half of the nineteenth century. In the late twentieth century legislative and policy-making measures adopted by the World Trade Organisation are similarly constructing technology markets by universalising the US patent system. Once again there is nothing spontaneous, automatic or natural

Javed A. Ansari is Dean at the College of Business Management, Karachi, and Rafique A. Khan is based at the Institute of Health Management, Baqai Medical University, Karachi. 
about the processes of legitimisation which reduce the access of developing countries to the new technologies.

Capitalist markets and capitalist property forms are thus historical constructions in the specific sense that laws and practices are "required" for their emergence and their sustainence. Outcomes of course need not have been as intended but a certain easily definable ethos motivated the actions which led to the development of capitalist property. Historically constructed markets cannot be viewed as natural outcomes of myriad unrelated events or attributed to the natural evolution of technology [Polanyi (1947)].

The historical political construction of the capitalist property form rules out the possibility of its defence on grounds sanctioned by natural law. ${ }^{1}$ Markets are premised on the existence of morally sanctioned property rights-rights about ownership, exchange and unrequited transfer. Conceptions of ownership with respect to human bodies, life forms, water and land have varied among societies and there is nothing "natural" about any particular answer to property rights legitimising questions. Similarly, a property-defining authority must be morally sanctioned. Since moral sanctioning requires an exercise of political power, the state necessarily plays a major role in defining and enforcing the legitimisation of a particular conception of property rights.

Capitalist markets structure price-based decision-making between anonymous individuals. Unlike feudalism, social positions do not define exchange relationships. Feudal exchange was contextualised by a set of rules and traditions which left little scope for price based choices. Similarly, exchanges between citizen and government of even the most mature capitalist state in history do not constitute a market relationship because a citizen cannot directly choose the services he receives or the taxes he pays to government. Non-market exchanges are, however, increasingly exceptional in capitalist civil societies and price-based exchange among anonymous buyers and sellers usually dominate. Market relations are the main determinant of the pace and pattern of economic activity. As Polanyi puts it, "(capitalism) is the running of society as an adjunct to the market. Instead of the economy being embedded in social relations, social relations are embedded in the economic system” (1947, p. 57). So defined, capitalism is seen to be necessarily spatially and temporally specific. ${ }^{2}$

The continued dominance of the capitalist property form requires that legitimate power be transferred to those who can best organise production and exchange for accelerated accumulation, directly (i.e. in the circuit of capital) or indirectly (in the super-structure). ${ }^{3}$ This implies a universalisation of the wage form - for it is the wage form which structurally relates rewards to efforts.

${ }^{1}$ Non capitalist property forms also cannot be so defended-there is nothing "natural" about feudal or socialist property forms: their defence must also be premised on moral grounds.

${ }^{2}$ Thus, we can state that capitalism probably did not exist anywhere in the world in 1066. It did exist in North East England in 1858 and was abolished in the Khost province of Afghanistan in 1997.

${ }^{3}$ In spheres such as politics, culture, scientific research which facilitate accumulation. 
Capitalist property is not private because it is dedicated to accumulation. Control of this property is effectively vested in individuals who possess the skills and knowledge to accelerate efficient accumulation. They "manage" capitalist property on behalf of its formal owners and rewards to both "owners" and "managers" correspond to success achieved in the use of resources to accelerate efficient accumulation. The wage form is universalised in two ways (a) accelerated efficient accumulation implies increased centralisation and concentration of capital and hence a reduction in the section of the population which is not dependent on waged or salaried labour, as a main source of its incomes and (b) even these property "owning" individuals become crucially dependent on the skills of the dominant salaried "managers" to accumulate efficiently. ${ }^{4}$ As Meszaros writes "(T)he capital system is (the) first one in history which constitutes itself as an unexceptional and irresistible totaliser. This characteristic makes the system more dynamic than all the earlier modes of social.... control. But the price that must be paid for this incommensurable totalising dynamism is... the loss of control over the decisionmaking process. This applies even to the richest capitalists for no matter how many controlling shares they own, their power of control within the framework of the capital system is quite negligible. They must obey the objective imperatives of the system just like every one else or suffer the consequence and go out of business". (1995, p. 41-42).

Universalising wage labour is thus an aspect of the dominance of marketsthe late twentieth century has seen significant growth in market dominance. But markets continue to be regulated. The state plays a role as both regulator and supporter of markets. Both regulatory and support systems have their origins in national and local histories. It is therefore legitimate to speak of the co-existence of several capitalisms - several market dominant social formations-in the early 21st century. Moreover, the forms and intensity of regulation and support continue to change so we can also legitimately speak of a continuous construction of capitalisms. In the twenty first century, capitalist governments or state agencies are not the only sources of market regulation-much regulation and reconstruction of markets is undertaken by the monopolists, monopsonists, oligopolists and oligopsonists who normally dominate capitalism. These "private" organisations seek to capture the "public" resources and institutions which are involved in market regulation and construction. Interaction between "public" and "private" agents establishes a historically specific regulatory regime which defines the scope of capitalist markets and the manner in which they perform their functions. The development of historically specific regulatory regimes may involve a transition from non-capitalist to capitalist property forms or a transition from one capitalist property form to another. It is the duty of the capitalist state ${ }^{5}$ to de-legitimise and obstruct a transition

4“Owners” would find that they are holding valueless bonds and shares unless managers succeed in ensuring high profitability.

${ }^{5}$ Written into the US constitution by the Fifth Amendment. 
from capitalist to non-capitalist forms of property. This illustrates that capitalist property, is a historical not a natural construct. It necessarily requires moral legitimisation.

Such a justification has been provided by Hegel. He sees capitalist society and the state as the final stage in human history. This final order of universal permanent capital reflected the self-realisation of the World Spirit. For Hegel, historical time was a relentless forward movement realising the idea of freedom. Hegel's thought has Smithian roots. He took for granted the hereafter permanence of capitalist civil society. ${ }^{6}$ Hegel's “cunning of Reason" is simply another-more profoundconceptualisation of Smith's " invisible hand" ${ }^{7}$-for it represents the eternalised standpoint of capitalist civil society and nothing else. It was Hegel who wrote, "Europe is absolutely the end of history" (1956, p. 103). Transition to a non-capitalist social formation is not only unreal but irrational and the ground is cleared for the neo classical equilibrium analysis which admits of only marginal adjustments to the finally attained universal capitalist order which 'is the destiny of Reason itself' [Hegel (1956), p. 107]. The mass slaughter of the Red Indians, the colonisation of the East, the dehumanisation of an uprooted peasantry in Europe-these are viewed as moments in the realisation of this ultimate triumph of Reason. Opposing capitalism was thus violating the requirements of Reason itself and what else could be more reprehensible?

Hegel succinctly sums up his argument identifying Reason with the movement of capital. "By a dialectical advance subjective self-seeking turns into mediation by the particular through the universal with the result that each man in earning, producing and enjoying on his own account is eo-ipso producing and earning for the enjoyment of everyone else". ${ }^{8}$ The compulsion which brings this about is rooted in the complex interdependence of each on all and it now presents itself to each as universal permanent capital [Hegel (1942), p. 129-30].

In section 200 of his Philosophy of Right Hegel explicitly justified capitalist civil society on the ethical ground that participating in general wealth through one's skill (labour) is determined by access to capital. Hence, he regards capitalism as an ethically grounded order which is legitimately universalisable and necessary to the realisation of freedom. A moral social order dominated by ever expanding capital is a "rational necessity of freedom". In the Hegelian system, despite a recognition of its "accidental, contingent" historical roots ${ }^{9}$ permanent capital is regarded as a fully dehistoricised entity: hence the "irrationality" of moral/social projects seeking transcendence of capitalist processes. The capitalist mode of production and its associated inequalities in the distribution of power and income is quite explicitly defended by Hegel on grounds of rationality (1942, pp. 129-30).

${ }^{6}$ Quite explicitly identifying civil society with the market in The Philosophy of Right.

${ }^{7}$ Or Kant's "plan of nature" or Vico's "providence".

${ }^{8}$ Echoes of Smith.

${ }^{9}$ These are mentioned no less than six times in sec. 200 of The Philosophy of Right. 
It is thus legitimate to avoid the problem of capitalism's historical origins because in the Hegelian and neo-classical perception, capitalist order is a rational necessity for freedom. This view can be rejected on the basis of two quite separate grounds. We will consider each briefly.

Marxists accuse Hegel of misrepresenting the nature of "the complex interdependence of each on all”. In the Marxist view, this "complex interdependence" does not invalidate the need to transcend the class division of capitalist civil society. In this view, capital is a historically transcendable property relationship which dominates individuals (both labourers and capitalists). The class struggle is the essential modus vivendi for the transcendence of capitalist order and for the realisation of freedom. The existence of capital makes freedom impossible: for according to the Marxists there is an absence of reciprocity in capitalist civil society which is dominated by a structurally safeguarded exploitative hierarchic self-seeking particularity and the contradictions it generates inhibits freedom. It creates chaos not harmony. Capitalism frustrates the quest for freedom through alienation in the process of production. The inherently crisis ridden character of capitalism demonstrates its irrationality as a means for the realisation of freedom [Marx (1954) and Meszaros (1970)].

A more fundamental rejection of capitalist rationality-its "universal permanence" - is embodied in the Christian and Islamic repudiation of freedom as an individual or social aspiration. Christianity and Islam ground moral and ethical order on the duty to surrender to God's will and seek to promote the type of virtuous lives which articulate and actualise this surrender: Islamic and Christian public orders are virtue-not welfare-centric. The Christian-Islamic rejection of the universal permanence of capital is an aspect of their rejection of the eternity of the world.

As Tawney (1959) shows, capitalism systematically undermines Christian virtue. Before the Enlightenment economics was subsumed by ethics and ethics by theology. ${ }^{10}$ Economic evaluations were subject to religious norms and Christianity and Islam emphatically reject the claim that the attainment of material well-being (i.e. maximising the present discounted value of consumerables in a finite life time) can be a valid criteria for evaluating success. As Tawney writes, "the philosophy of (welfare) is a negation of any system of thought or morals which can....be described as Christian. Compromise is impossible between the church of Christ and the idolatry of wealth” (1959, p. 280).

The Christian-Islamic rejection of capitalism ${ }^{11}$ centres on the universalisation of usury and the disappearance of the just price within capitalist

${ }^{10}$ Theology was grounded on a specifically Christian-Islamic metaphysics which provided a moral base for ethical evaluation.

${ }^{11}$ Even in a puritanical text such as Pilgrims Progress Christian and Faithful (i.e. Momin) are shown to suffer persecution together in Vanity Fair (which may be interpreted as the public order of capital). Faithful is martyred in Vanity Fair [Bunyan (1987), pp. 85-87]. For an interpretation of Vanity Fair see Sharrock (1966, pp. 71-90). This illustrates the common stance taken by Islam and Christianity with regard to capitalist public order. 
order [Tawney (1959), p. 48-67; Thanvi (1934), pp. 117-149]. This leads to the dominance of the vices of avarice (accumulation) and covetousness (competition) in the life of the individual and of society. Public orders and private lives become forgetful of being and of death and therefore incapable of love.

Accepting capital as "permanent universal" thus depends upon:

- Continued forgetfulness of death and of being and rejection of Christian Islamic conception of virtue and of the triviality of this world. This implies the continued hegemony of what Raz calls "the morality of freedom".

- Continued acceptance of income and power distributional inequalities of capitalist order as non-transcendable; (but subject to mediation).

- Continued acceptance of capital's ability to expand the realm of freedom for its subjects both in civil society and in the state.

\section{PROCESS}

The starting point for understanding capitalist process should of course be mainstream economic theory. Since the late 1970s, there have been several important methodological advances in mainstream theory and as Fine puts it " the political is being put back into economic analysis" (1997, p. 145), through for example segmented labour market theory and analysis of rent seeking behaviour. But such broadening of scope does not amount to a departure from methodological individualism. The "giveness" of preferences ${ }^{12}$ and the compulsion to optimise are retained as underlying assumptions of household behaviour, educational choice and trade union action. Methodological individualism now occupies those sub-disciplines (development and urban and labour economics for example) from which it was previously (partially) excluded. The state itself is (absurdly) viewed as an individual with given preferential trade offs between potential policy outcomes. Institutional economics has also developed theories explaining the collective behaviour of optimising agents.

Endogenous growth theory has also sought to open up the black box of the technological residual in a typical Solow-Dennison type production function. This has partially legitimised "capacity building" policy initiatives at the micro and macro levels - without calling into question the relevance of rational expectations " in the last instance”. The emphasis laid on the role of human capital [Lucas (1988)], producer durables and "ideas" creates a possibility of going beyond equilibrium analysis and developing a deeper understanding of (optimising) choices. But the policy prescriptions of endogenous growth theory have not been validated by empirical evidence. ${ }^{13}$ As Ruttan argues, why "capability building is more successful

${ }^{12}$ And often also of production possibilities.

${ }^{13}$ Thus as is now widely recognised East Asian and Soviet growth was sourced by an accumulation of physical resources not an increase in factor productivity. Despite emphasis on openness and human capacity building growth in the OECD during the last two decades has remained low. Empirical studies have shown that scale economies are not important sources of growth. 
in specific cases is not adequately explained by endogenous growth theory. It does not have the capacity to reach behind the "proximate" causes of growth and understand "pre-conditions" and "take off” stages (or processes)" (1998, pp. 24-25). It is the commitment to methodological individualism (commitment to the "giveness" of preferences and the "universality" of optimising behaviour) which is the dominant constraint on the indigenous growth theory's ability to understand capitalist process. This theory-like all other manifestations of the "new" economics-accepts as unproblematic the "universal permanent" character of capitalist expectations, markets and governance processes. It is thus inevitable that it can say little about possibilities/strategies for ensuring or undermining the continued universal permanence of capitalist order.

Economic theory's commitment to the non-problemitised universal permanence of capitalist order is reflected in its commitment to a premise of homogeneity. Economics is inspired by liberal political thought and aspires to describe a "pure" economy governed ultimately by Natural Law [Keat (1993)]. In this perspective, Riffat is committed to a supposed universal rationality (optimising discounted consumption flows over a finite lifetime). Commitment to such rationality and the added assumption of competitive equilibrium also implies Riffat's awareness of the (total) web of (human and natural) relationships which structure/constrain her use of resources. ${ }^{14}$ In this sense, a general equilibrium system is completely centralised in that the characteristics of the system are in the minds of all interacting individuals and they all effectively behave as a single individual (Riffat is alone in her own universe). This commitment to homogeneity necessarily rules out the possibility of policy effectiveness-as rational expectations based models have so often demonstrated.

Actually existing capitalism (in all its historical stages) is characterised by both heterogeneity and coherence. Riffat's behaviour is often "irrational" (nonoptimising and or based on imperfect information). Yet, there is sustainable coherence of behaviour patterns reflected in the normal practices of markets and states. Economics explains this coherence by attempts to identify the microeconomic foundations of the macroeconomy ${ }^{15}$ - the macroeconomy is treated effectively as an aggregated microeconomy. "Adding up" micro level outcomes and systematically ignoring relational complexities at and between economic levels is seen as unproblematic by (at least) neo classical economics.

Twenty first century capitalism is likely to be characterised by increased heterogeneity. Differential access to information creates asymmetries of influence and power. Moreover, increased externalities are also limiting the homogenisation effects of market allocative processes. Regulation theory [Agleitta (1999)] asserts

${ }^{14}$ This commitment to homogeneity is retained in socialism for as Oscar Lange has demonstrated perfect competition and perfect planning are identical.

${ }^{15}$ Thus retaining its commitment to homogeneity. 
that coherence in increasingly heterogeneously structured capitalist order is not spontaneously maintained by market processes but generated by a specific "mode of regulation" characteristic of and appropriate to a specific historical phase of capitalist development (Victorian, Fordist, Post Fordist etc.). A "mode of regulation” is a set of mediations in a capitalist civil society and state which ensures that structural (relational) distortions created by a specific accumulation regime do not destroy social coherence within a particular political order ${ }^{16}$. These mediation mechanisms validate the pursuit of differentiated individual interests within a system of power relationships themselves legitimised by common social objectives. ${ }^{17}$

Since money is the basis of capitalist order ${ }^{18}$ accumulation of capital is the accumulation of power - the desire to accumulate money/power infinitely is universally dominant in capitalist order. The movement of money capital determines the division of labour, structures the employer-employee relationship and dominates the private and public lives of both "capitalists" and "labourers". This dominance of money capital is a pre-requisite for assigning relative value to economic activities in accordance with their (relative) contribution to accumulation. Capitalist order thus requires:

(a) Universal dominance of the desire to accumulate capitalist money/power ${ }^{19}$.

(b) Continued expectation of increased access to capitalist money/power.

Subordination to the desire to accumulate takes place most formally at the level of the enterprise: This subordination has a collective character. Collectively labourers are subordinated to the authority of managers. Collectively managers are dependent on consumers. Accumulation necessitates the systematic taking of risks to bring about structural changes in the division of labour. Investment risks cannot be taken without the enhancement of indebtedness-hence the universality of the continual buying and selling of debts and rights to capital use and the evaluation of these claims in financial markets within capitalist order. These evaluations are speculations on the future. Doubts about solvency of risk takers and their financiers may lead to major changes in financial evaluations by firms, banks and macro economic managers. Hence sustaining capitalist orders also requires.

(a) Efficient mediation to ensure compatibility between financial claims and obligations for continuing accumulation.

Policy is required to ensure the continued existence of (a), (b) and (c). Capitalist order is not spontaneously generated in the spheres of production and

\footnotetext{
${ }^{16}$ This has usually taken the form of a nation state in the 19th and 20th centuries.

${ }^{17}$ Thus, Keynes recognises both conflict in the interest of financiers and investors and the need to reconcile them to move out of a state of less than full employment equilibrium.

${ }^{18}$ Treating it as such transforms money into capitalist money [Itoh (1999), pp.101-107].

${ }^{19}$ This includes the condition that individuals not regarding money/power accumulation as legitimate ends are compelled to participate in accumulation processes as "mustadafeen".
} 
finance or within the social sphere, ${ }^{20}$ and it is not self-perpetuating - hence the possibility of crises emerging from the non-realisation of (a), (b) and /or (c). Policy may be regarded as successful if it strengthens the social dominance of the desire to accumulate money/power, facilitates such accumulation by dominant individuals in different social groups and articulates an effective debt management strategy. Policy is a means for linking different segments of the micro-economy within the context of a particular macroeconomic coherence. In capitalism enterprises, (firms and banks) are important co-ordinating links between the micro and macro economy. The enterprise structures rules of payments, flows of goods and financial relationships into a hierarchy relating stake holders with claims/obligations on the collectively produced added values. These structures are created by collective and, therefore, necessarily political actions. The political nature of the mediation process is a reflection of the underlying tension between the continuing need to accumulate and the continuing need to legitimise particular forms of accumulation. The maintenance of social cohesion requires this continuing legitimisation.

In the twentieth century, successful mediation has taken the form of creation of a high wage society. This has often entailed rising fiscal costs but has given collective purpose to the pursuit of private interests. In twentieth century capitalism of the "Butskellist" ${ }^{21}$ variety subordination at the level of production of the individual worker was legitimised by the provision of collective rights. This form of mediation was established not spontaneously but through continuing political negotiations between the representatives of capitalists and labourers. This was "Fordism". It entailed

(a) Constraining accumulation to integrate labour interests in the accumulation process.

(b) Increased oligopolistic domination of product and factor markets.

(c) Consolidation of trade union strength, proliferation of collective bargaining processes and the establishment of the full time, long term wage contract as a norm.

(d) Restriction on the mobility of capital (through the Bretton Woods regime).

(e) Substitution of traditional identities (Christian, Irishman, mother) with new identities (trade unionist, manager, professional). Stratification within Fordist organisations related social mobility to success in the accumulation of power/money. But Fordist hierarchies also restricted social mobility in a manner, which reduced uncertainty for both labourers and managers.

Breakdown of a mediation regime, (say Fordism) may be interpreted as the consequence of a break down of interactions between mediation mechanisms which are concerned with balancing divergent aspects of regimes of accumulation. Thus,

${ }^{20}$ Or within the consciousness of individuals.

21،Bustskellism" was the Keynesian consensus characteristic of the policy stance of the Conservative and Labour parties in Britain during 1951-1964. 
Fordist organisation facilitated both security and mobility. It was compatible with pluralist order, which has space for personal autonomy. But tensions are necessarily involved in managing autonomy and subordination and the possibility of the emergence of a recurrent sub-optimal equilibrium (recession) or disequilibrium (crisis) cannot be ruled out.

The core of the Fordist regime was the achievement of a stable relationship between productivity and wage growth. As Mosley (1999) argues the rate of profit and the share of capital in national income remained stable for most OECD countries during 1950-73. Social expenditure and associated investments were counter cyclical in nature, ${ }^{22}$ as were expectations. Fiscal policy swamped the effects of monetary policy and investment was highly leveraged. Widespread exchange controls meant that government could easily play a policy-coordinating role at the national level. The state's role in the building up of scientific, technical knowledge and in the subsidisation of (private) investment risk was of vital importance in sustaining Fordism - this involved strict regulation of financial markets and state control over financial intermediation processes. Finally the Fordist regime strongly encouraged consumerism and hoped that the universal adoption of consumption expansion oriented lifestyles would strengthen citizenship and labourers' incorporation within capitalism.

The literature attributes several reasons for the breakdown of Fordist order [Lash and Urry (1987); Hirst and Thompson (1997); Agleitta (1999)]. These include (a) globalisation of production and financing systems (b) changes in production and exchange technology (c) deproletarianisation of the labour class and (d) atomisation of social life (and destruction of communities) specially in the OECD countries. "Post Fordist" order is characterised by growing full time unemployment, increased maldistribution of income (specially in the United States) the spread of consumerism to many Third World countries, the growth of part time employment, cheapening of the cost of financial and technological transfer processes across national frontiers, widening of differentials in inter sectoral productivity growth rates and changes in demographic structures.

Effective mediation processes are required for sustaining "post Fordism"-it is not a self sustaining order. Fordist mediation structures are collapsing. Mediation within the work process continues with collective bargaining being replaced by human resources management. As monopolistic competition increases organisational changes in firms and state bureaucratic decision-making structures facilitate outsourcing, "automation" and the growth of "flexible specialisation". All these are mediated, not spontaneous, responses. A new compatibility between the accumulation regime and the social commitment to capital's hegemony is being created and needs to be sustained. There is a continuing need to legitimise.

\footnotetext{
${ }^{22}$ Typically public investment "crowded in" private investment in the Fordist era.
} 
(a) The subordination of national public transport, energy, communication, and financial sectors to international capital.

(b) The marketisation of public sector (including nationalised industry) wage contracts.

(c) The determination of wage levels within processes of international competition leading to a widening of wage differentials in national economies.

(d) Enhanced systemic mobility of capital (but not of labour since there is no relaxation of immigration controls).

(e) Abandonment of full employment as a goal of macroeconomic policy.

(f) Abandonment of state regulation of financial markets and increased dependence on foreign financial flows. ${ }^{23}$

(g) Higher financial returns in both capital and money markets. As institutional savings rise and household savings fall the institutional investment manager becomes the dominant influence. He puts a premium on high financial returns in the short run and firms are forced to cut wages under threat of mergers and leveraged buy-outs.

(h) The dominance of financial markets-and therefore of national economies-by non-bank financial intermediaries which specialise in dividing risk associated with market finance into their elementary components and making them negotiable. Risk sales of this sort have led to the emergence of colossal markets in global liquidity. States increasingly articulate accommodative macro strategies to fall in line with the preferences of these new global financial giants.

(i) The growth of individualism and the weakening of the type of collective expression of individual aspirations that Fordism facilitated.

(j) The new compartmentalisation of the work process associated with the increased application of information technology. This has led to an individualisation of the effort and remuneration system. Labour market uncertainties have increased and career patterns have also been individualised. Socio professional and work rules within organisations have changed in response to the spread of IT. Worker loyalty to firms has declined. Inequalities are assuming an anarchic character.

\section{SOCIAL DEMOCRATIC REFORMS}

Legitimising post Fordist capitalism requires political medication. Capital may be defined as "ever expanding exchange value in the form of pure quantity" [Meszaros (1995), p. 115]. This corresponds to the Christian-Islamic concept of

${ }^{23}$ This is specially important for the United States which is now a net international debtor and as Mosley (1999) argues much of the American growth resilience during the 1990s has been due to high foreign capital inflow. 
avarice/takathur. ${ }^{24}$ Capital may also be defined as the concrete form of freedom [Suri (1999)]. The enlightenment's triumph over Christianity is essentially the triumph of freedom over love as the purpose of individual and social being. Freedom-a continuing self-justifying quest for mastery over creation including most importantly the self creation of humanity -is the consensual value of Enlightenment and Post Enlightenment social order ${ }^{25}$ [Arshad (1999)]. In this sense, neither social democracy nor any other intellectual or political movement inspired by enlightenment ontology can reject capital for this would amount to a transcendence of freedom in its concrete form and submission to God's will.

Social democracy thus rejects not capital but certain aspects of capitalism. We will now briefly survey the reforms proposed by three leading social democrat thinkers to enhance the capacity of the capitalist system to achieve freedom and its associated justices ${ }^{26}$ - these proposals vaccillate between arguments for a modification of Post Fordism and a return to Fordism.

For Habermas actually existing capitalism's defining characteristic is its super-territoriality. He describes the present era is "a post national constellation" (1999) and suggests that there is no alternative to post nationalism. In Habermas' view, the greatest failure of this post national capitalism is its production of mass unand under-employment. The state has lost fiscal authority because politics remains national unable to deal effectively with its super-territorial constituents. There must now be a democratically legitimised exercise of political power "above" the legislative levels of the nation state so that a super-national social contract can be constructed and a super-national welfare state willed into being. Habermas pins his hope in a federal Europe which will constrain the inequality generating tendency of the transnational enterprises and eliminate the need for competition among nation states (specially, competitive devaluation) to attract and retain investment.

Constructing "Federal Europe" in Habermas' perception must involve both the formulation of a new political constitution and the evolution of a distinctively European civil society. The constitution must preserve the idea of a self-determining community and intellectuals must struggle for the creation of a European public sphere. Habermas is aware of the lack of popular enthusiasm for such political projects - he laments the "issue less" elections which brought Schroder to power and the continuing decline in voter turn out (specially in elections for the European parliament). He however, rejects Luhman's image of a media driven society. The public is fragmented and distracted but Habermas asserts it retains a capacity to weigh competing arguments. The defense of the public communication sphere which

\footnotetext{
${ }^{24}$ Imam Muhammad Marmaduke Pickthall (1937, p. 941) defines "takathur" as "rivalry in worldly increase" combining the Christian conceptions of covetousness (competition) and avarice (accumulation).

${ }^{25}$ According to Rorty "a liberal society is one which has no ideal except freedom" [in Bhasker (1991), p. VII].

${ }^{26}$ Most effectively summarised by Rawls (1971) in his seminal contribution.
} 
links the "public" with decision-makers remains very important. But "meaningful" and effective public communication requires that market forces should not dominate the communication networks - these networks are replacing the political party as a channel of interaction between the "public" and decision takers.

Habermas accepts the inevitability of mass unemployment. He advocates the "redistribution of a lower volume of necessary labour" and shifting the burden of the cost of unemployment from the unemployables to "society". This requires a strengthening of "the egalitarian self-understanding of society". Opposition to the enhanced regulation of society entails a "social fatalist" ideology which legitimises the pursuit of individualised purposes in the context of a value free institutional network. This is an abandoning of consensual values and hence of democracy. ${ }^{27}$ Habermas' commitment to a pluralist democracy based upon a respect of the "autonomy of the individual" provides the ideological ground for the reforms he suggests. ${ }^{28}$

Agleitta endorses the commitment to democratically generated consensual values. In his recent reformulation of regulation theory Agleitta (1999) deemphasises the role of enterprises as the co-ordinating links between the micro and the macroeconomy. Agleitta now regards the history of capitalism as the history of the development of a high wage society. Contemporary high wage society faces three major problems according to Agleitta (a) globalisation (b) threat to social identity and (c) the "shrinking" of the state. New mediation mechanism for reestablishing a high growth regime are gradually emerging. The key features of the new system are (a) expanded competition specially in labour markets (b) control of enterprises by institutional share holders (specially fund managers) and (c) the establishment of market valuation as the basic criteria for social success.

Mediation mechanisms must be evolved to benefit from these "key features". Agleitta suggests that the emergence of institutional funds provide an opportunity for the trade union. Trade unions must increase their ownership of company shares. This conversion of contractual savings into (collective) property rights will have decisive impact on the way enterprises are run and in their investment and employment policies. Trade unions could use pension fund ownership to protect management from hostile take over bids in return for a corporate strategy which pursues not high short term profitability but stable long term returns. With profitability ensured collective bargaining - at the level of the enterprises, the industry and the (super national) region, could acquire increased saliency.

${ }^{27}$ Habermas believes that defending democracy is a common project which links Anglo-Saxon analytical philosophy and continental philosophical schools. He regards the work of both Brandon and Rorty as fundamentally in the Hegelian tradition (Habermas, forthcoming).

${ }^{28}$ According to The Post National Constellation values endorsed by Habermas include (a) respect for the particularity of strangers (b) international co-operation (c) autonomy of individuals and plurality of identities (d) suspicion of any "rhetoric of the high or the deep" and (e) resistance to the trivialisation of "the life of the mind". 
Agleitta also calls for a change in the role of the state to tackle the problem of endemic mass unemployment. Training programmes must be designed by government to cover the entire working life of each member of the labour force- the state must be able to offer employers a labour force with a constantly rising skill level. Every labourer must periodically return to the training process, and skills acquired must be transferable between enterprises. Job contracts should facilitate mobility and this should be used as a means for enhancing workers negotiation skills. There should be a deliberate fusion of public and private finance to achieve these ends. Capitalism needs an "investing" not a minimalist state. The new "division of labour" between capitalism's public and private spheres calls for an enhanced role for the states in the production of technological knowledge ${ }^{29}$ but the utilisation of these resources must be left to the private sector.

Agleitta recognises that his proposed mediation mechanisms are compatible with globalisation, the social primacy of markets and the greater mobility of labour. They come into play before the operations of the price system. But they are not a means for addressing the problem associated with growth of rising inequalities and declining social solidarity. Solidarity requires that the nation as a whole take the risks that threaten life in society. Agleitta endorses Rawls "difference principle" in the statement that "real freedom in a society can be measured only by the resources of its poorest member" (1999, p. 54). The disintegration of the Fordist regime of accumulation has weakened democracy in the West and there is a need to redefine social rights. In Fordism, these were defined with reference to occupational solidarity. This solidarity has broken down and there is now a need to assert the "right" that exclusion from society cannot be tolerated. Freedom from social exclusion must become the categorical imperative of the state and the supreme aim of social democracy - Agleitta recognises that this involves significantly higher taxation levels. A central concern of the reform movement should be the provisions of a minimum income to all which is sufficient to ensure that everyone can effectively access Rawls "primary goods". ${ }^{30}$ The agency for creating this new social solidarity should be a broad coalition of the single issue movements (eco-feminism, animal rights, disarmament, gay rights etc.) which have dominated resistance politics in the West in recent years.

A concern with social solidarity is also central to Rorty (1998). This, in his view, can be built only on the basis of renewed "national pride". Such national pride must emphatically reject the view that democracy has become a farce. We "should abandon the question; why should we prefer democracy to obedience in favour of the question; given the preference we Americans have what should we say about truth, knowledge, reason, virtue” (1998, p. 27-28). The preference for democracy needs no

${ }^{29}$ Justified by the existence of externalities.

${ }^{30}$ According to Agleitta, this guaranteed minimum income should be provided by the state. Its' provision can therefore reduce the wages paid by companies. 
justification and justifies national crimes such as the wholesale massacre of the Red Indians $^{31}$ and the slaughter of the Vietnamese [Rorty (1998), p. 32]. Social democracy must use democratic institutions to serve the cause of "social justice". The concern must be the "combining (of) political freedom with centralised economic decision making” [Rorty, p. 79]. Social democrats should target growing economic inequality and economic insecurity. Rorty sees possibilities of populist revolt in the "prolitarianisation of the Americans bourgeoisie." (p. 83).

Rorty believes that "things will get much worse much faster ... The world economy will soon be owned by a cosmopolitan upper class which has no sense of community with any workers anywhere” (p. 85). Rorty also deplores America's growing dependence on foreign capital (p. 86) and increased free trade (p. 88). He sees a conspiracy "of the super rich to keep the minds of the population elsewhereto keep the bottom 75 percent of Americans busy with ethnic and religious hostilities" (p. 88) and fears that fascism may be America's future (p. 89). "The non suburban electorate will decide that the system has failed" [Rorty, p. 91]. Social democrats should counter this by (a) putting a moratorium on theory-forgetting the awkward questions raised by Lacan, Lyotard and Derida about the multiple incoherences characteristic of this type of vulgar communitarianism (b) mobilise national pride in being American and (c) concentrate political attention within the context of the nation state. This should provide a basis for a people's charter and an alliance with the trade unions. Social democrats should recognise that participatory democracy is an illusion and that there is no alternative to capitalism. Piecemeal reform within the framework of a market economy should be the main concern of social democracy.

Achieving our Country is a polemic against the very widespread disillusionment with liberal democracy in general and "piecemeal reform within the framework of a market economy" in particular-this is reflected in books such as those by Stephenson (1988) and Jameson (1992) and the rightward shift of the Democratic party. This shift is also mirrored in the national programmes of the social democratic parties of Blair, Schroder and Jospin. John Gray, one of Europe's leading political thinkers, regards Rorty's vulgar communitarianism as a "shallow and ultimately incoherent perspective” (1998, p. 146). In Gray's view, capitalism undermines itself by unleashing forces that destroy the institutions necessary for its survival. He maintains that the Enlightenment project of promoting autonomous reason as the basis of morality has proved to be self-destroying. The post-modern condition of fractured perspectives and groundless practice brings not just disenchantment but threatens the very existence of Western civilisation (1995, Chp. 2). If globalisation is not checked, Gray believes it will lead to war, impoverishment and the break down of social cohesion. Globalisation crucially undermines democracy by making social democratic practices (specially Keynesian policies)

${ }^{31}$ Around 7 million Red Indians were killed during 1750-1890 [Dee (1971), p. 147-161]. 
impossible. The free market is remorselessly destroying American social cohesion by deepening insecurities and corroding the basic institutions of bourgeois life (specially the family). Gray takes comfort from the fact that the United States does not have the power to impose a universal free market all over the world. Resistance to globalisation is possible but Gray believes that the most likely outcome of the American attempt to impose the free market on the rest of the world will be increased chaos and disorder, sparking off a wave of social and financial turmoil which will eventually engulf the United States. He writes, "global capitalism is inherently ungovernable” (1999, p. 209). In Gray's perspectives, capitalism will not survive as a unified global system: Attempts to stamp a free market model on all countries by the USA, the Fund and the Bank, will have terrifying consequences: Resistance to such attempts through augmenting national autonomy is urgently necessary. Nevertheless such resistance will merely create "a fragmentation of the world economy into predatory regional capitalisms” (1999, p. 263).

Noam Chomsky is equally pessimistic. In his view (1998), the free market is a myth. Capitalism today is a "system of administration of markets by collectivist legal enterprises-mergers, cartels, corporate alliances-in association with powerful states and international bureaucracies which regulate and support private power" (1998, p. 5). Chomsky notes that concentration and centralisation of power and privilege is growing, union victimisation has increased and wages of two thirds of American labour in 1998 were below the 1978 level (1998, p. 12). State initiatives remain crucially important for sustaining capitalist profitability and concentration ${ }^{32}$ and "naturally business is delighted with this. The public pays the costs, assumes the risk while profits and power are privatised" [Chomsky (1998), p. 14].

Increased concentration and centralisation implies that democracy has rising costs - hence the continuing resistance to the growth of social spending. Moreover, liberalisation of the financial system is a powerful weapon against the welfare state it systemically undermines popular sovereignty and creates what Mahon has called "a virtual senate" (1996, p. 10). Mobile capital has the powers to impose its own social policy upon the democratic state. Mobile capital-95 percent of which is speculative and short term in nature-imposes a low growth, low wage macroeconomic strategy specially on developing countries and significantly increases their vulnerability to wild fluctuations in world financial markets. Mobile capital transfers sovereignty to the giant banks, financial intermediaries and firms, which effectively administer the globalised economy. The political power of MNCs, international funds and banks, has been greatly increased by the odious debt ${ }^{33}$ that

${ }^{32}$ Chomsky demonstrates this with reference to the crucially important role of public sector investment in the development of the internet, information processing, lasers, satellites and transistors (1998, p. 13-14).

${ }^{33}$ When the United States colonised Cuba in the late nineteenth century it cancelled Cuba's debt to Spain on the grounds that the debt was imposed upon the people of Cuba without their consent. Legal treatises call such debt "odious debt" and recognise "no obligation for the nation. (This debt) is the responsibility of the power that has imposed it" [Adams (1991), p. 17]. 
has been imposed upon developing countries by the United States the IMF and the World Bank [Strange (1998)]. The formal acknowledgment of this transfer of sovereignty from the nation state to the corporation is contained in the OECD's. Multilateral Agreement on Investment (MAI) which is now being championed by the IMF. This transfer of political sovereignty from states to international corporations is also the primary objective of the amendment to the IMF's first Article of Agreement mandating capital account convertibility. Such a transformation of course makes social democratic reform impossible.

\section{CONCLUSION}

Social democracy and its proposed reforms are both necessary and impossible (in a Sartrean sense). As Chomsky notes, "the long term goal of modern capitalism (is to create) an international political economy which is organised by powerful states and secret bureaucracies whose primary function is to serve the concentration of power which administer markets through their own internal operations, (and) networks of corporate alliances, including the intra-firm transactions that are mislabeled "trade". They rely on the public for subsidy for research and development, for innovation and for bailouts when things go wrong. They rely on the powerful states for protection from dangerous 'democracy openings'. In such ways, they seek to ensure that the prime beneficiaries of the world's wealth are the right people: the smug and prosperous Americans: and their counterparts elsewhere" [Chomsky (1998), p. 27].

Social democrats such as Agleitta and Rorty argue however that there are limits to the constraints that can be imposed on the democratic process. Constraining democracy is constraining capital itself-for capital is a concrete form of freedom. ${ }^{34}$ Social democratic reform is necessary in that it sustains faith in freedom through the promotion of both consumerism and participation in decision-making processes.

Thus, space seems to appear for the distributional reforms on the social democratic policy agenda. A developing country such as Pakistan clearly gains from resisting globalisation and the deceleration of growth, de-industrialisation and the financial sector volatility which globalisation entails. Mobilising resistance to globalisation cannot be undertaken on social democratic grounds however because social democracy does not delegitimise human rights discourse which is now a principle instrument for the atomisation of the individual and the destruction of collective identities specially in non western societies such as Pakistan. If political mediation processes remain dominated by human rights discourse, distributional issues will be addressed by poverty alleviation, basic needs type programmessponsored by the agencies of multinational capital. The central purpose of such programmes is thwarting the growth of collective rights and identities. The social

${ }^{34}$ As Suri (1999, p. 18) argues the circuit of capital is logically complemented by the circuit of citizenship since the vote is the abstract form of freedom. 
democratic agenda becomes irrelevant in such a scenario and countries such as Pakistan "leap over" the Fordist phase in the process of subordination to global capital. Even in western countries, a return to Fordism seems increasingly unrealistic as Lafontanie and Jospin have recently discovered.

Social democratic reform is impossible for twentieth century experiences have shown that accumulation/organisation of capital requires the atomisation/ disorganisation of labour. Traditional agencies for implementing social democratic reforms - trade unions, political parties, broad fronts, national governments-lose authority as capitalism matures: Hence a fundamentally important disjuncture of modern capitalism, the national organisation of democracy and the supra state organisation of markets cannot be addressed by social democracy-that is why despite Habermas' hopes federal Europe remains a neo liberal project and even social democratic parties adopt neo liberal policy stances with respect to European integration. This separation of the organisation of markets and states shows that growing exclusion and disempowerment of labour is necessary for growing concentration and centralisation of capital.

Nevertheless there are grounds for mobilising the excluded and the disempowered (the mustadafeen) in movements of resistance to capitalism. But such movements-unlike social democracy—will have to reject not just capitalism but avarice/takathur. They will have to de-legitimise freedom and re-legitimise love as the organising principle of human life at the level of both the society and the state. ${ }^{35}$ That however is another story.

\section{REFERENCES}

Adams, P. (1991) Odious Debts. London: Macmillan.

Agleitta, M. (1999) A Theory of Capitalist Accumulation: The US Experience. London: Verso.

Arshad, Z. (1999) Freedom in Modernist Discourse. Pakistan Business Review 1:2 44-50.

Bhagvati, J. (1998) The Capital Myths: The Difference between Trade in Widgets and Trade in Dollars. Foreign Affairs 77:3 7-12.

Bhasker, R. (1991) Philosophy and the Idea of Freedom. Oxford: Oxford University Press.

Brenner, R. (1998) The Economics of Global Turbulence. New Left Review 229: 1264.

Bunyan, J. (1987) The Pilgrims Progress. Harmondsworth: Penguin.

Byer, R., and D. Drache (1996) States Against Markets. London: Routledge.

Chomsky, N. (1998) Power in the Global Arena. New Left Review 230 3-27.

Collis, R. (1998) Ethics Man: John Gray's New Moral World. Political Quarterly 69:1 59-71.

\footnotetext{
${ }^{35}$ This is the common project of Christianity and Islam.
} 
Corbett, J. (1997) How Investment is Financed. The Manchester School 65:2 69-93. Dee, J. (1971) Bury My Heart at Wounded Knee. Harmondsworth: Penguin.

Fine, B. (1997) The New Revolution in Economics. Capital and Class 61: 143-149.

Fine, B. (1999) Addressing the World Economy: Two Steps Back. Capital and Class 67: 47-90.

Fine, B. (1999) Endogenous Growth Theory: A Critical Assessment. Cambridge Journal of Economics (forthcoming).

Gray, J. (1995) Enlightenment Wake: Politics and Culture at the End of the Modern Age. London: Macmillan.

Gray, J. (1999) False Dawn: The Delusions of Global Capitalism. London: Granta Books.

Habermas, J. (1999) The Post National Constellation. London: Verso.

Hayek, F. (1988) The Fatal Conceit. London: Routledge.

Hegel, F. (1942) Philosophy of Right. Oxford: Clarendon Press.

Hegel, F. (1956) The Philosophy of History. New York: Dover Publications.

Hirst, P., and D. Thomson (1997) Globalisation in Question. Cambridge Polity.

IMF (1999) World Economic Outlook 1999. Washington, D. C.

Itoh, M., and C. Lapavitsas (1999) Political Economy of Money and Finance. London: Macmillan.

Jameson, F. (1992) Post Modernism or the Cultural Logic of Late Capitalism. Cambridge Mass: Harvard University Press.

Jayne, G. D. (1986) Branches Without Roots. Geneses of the Black Working Class in the American South 1852-1882. New York: Oxford University Press.

Katz, D. (1994) The Social Structure of Accumulation. London: Cambridge University Press.

Keat, R. (1993) The Moral Boundaries of the Market. In C. Crouch and D. Marquand (ed.) Ethics and Markets. Oxford: Basil Blackwell. p. 16-20.

Keily, R. (1998) New Liberalism Revised. Capital and Clan 64: 63-89.

Lash, D., and Urry (1987) Unorganised Capitalism. London Polity.

Lucas, R. (1988) Econometric Policy Evaluation. In K. Brunner and A. Meltzer (eds) The Philips Curve and Labour Markets (2nd Edition). Amsterdam: North Holland. 73-94.

Lucklas, G. (1971) History and Class Consciousness. London: Merlin.

Mahon, J. (1996) Mobile Capital and Latin American Development. Pittsburgh: Penn University Press.

Marx, K. (1954) The German Ideology. Beijing: Foreign Languages Press.

Meszaros, I. (1970) Marx’s, Theory of Alienation. London: Merlin.

Meszaros, I. (1995) Beyond Capital. London: Merlin.

Mishel, M. (1997) The State of Working America 1996-97. New York: Sharp.

Mosely, F. (1997) The Rate of Profit and the Future of Capitalism. Review of Radical Political Economy 29: 23-41. 
Mosley, F. (1999) The US Economy at the Turn of the Century. Capital and Class 67: 25-49.

Pickhtall, M. (1937) The Glorious Quran. London: Brill.

Polanyi, K. (1994) The Great Transformation. Boston: Beacon Press.

Rawls, J. (1971) A Theory of Justice. Oxford: Basil Blackwell.

Rawls, J. (1995) Political Liberalism. Oxford: Basil Blackwell.

Rodrick D. (1997) Has Globalisation Gone Too Far. Washington, D. C.: NIESR.

Roemer, J. H. (1996) A Future for Socialism. New York: Harper.

Rorty, R. (1998) Achieving Our Country. Cambridge Mass: Harvard University Press.

Ruttan, V. (1998) The New Growth Theory and Development Economics. Journal of Development Studies 38:2 1-26.

Sharrock, R. (1996) The Pilgrim's Progress: A Critical Study. London: Arnold.

Silko, L. (1991) Almanac of the Dead. New York: Mentor.

Stephenson, N. (1988) Snow Crash. New York: Harper.

Strange, S. (1998) Mad Money. Manchester: Manchester University Press.

Suri, W. (1999) Some Contradictions of Capitalist Democracy. Pakistan Business Review 1:1 61-70.

Tawney, R. (1959) Religion and the Rise of Capitalism. Harmondsworth: Penguin.

Thanvi, Maulana Ashraf Ali (1934) Fadul al Ilm wal Khashiya. Hyderabad: Idara-IKhair-o-Islah. 


\section{Comments}

This paper is a breath of fresh air in the current neo-liberal discourse about economic development. Amidst all the talk about productivity, efficiency and good governance orchestrated by the international agencies, this paper springs from the left field both figuratively and literally. It asks us to stop and ponder over the assumptions and models of society and state embedded in the current economic paradigm. It builds on the neo-Marxist's critiques of the evolving economic order. Its philosophical approach and erudite arguments are the alarm bells for the conference of Pakistan Society of Development Economists. It calls the conferees to stop and reexamine the premises of their current policy prescriptions. It is an argument to promote arguments.

The argument proceeds on the premise that the capitalist markets are not natural outcomes of economic transactions but social constructs consciously manufactured, often by the state and its ruling elite. Capitalism is a choice and not natural occurrence. How the capitalist processes are being promoted in the late 20th Century is illustrated by the analysis of emerging post-Fordist order. The financial capitalism of the post-Fordist order requires regulatory support and institutional legitimacy. Again the state's authority is being mobilised to promote capital mobility and to dismantle national boundaries. I imagine even the current discourse of institutional economics falls in the category of structures that sustain new capitalism. Yet the crises of captialism are building up, the paper argues. The free trade, sloshing of speculative money around the globe and even the foreign investment all bear seeds of crises.

The last part of the paper brings up social democratic thinkers, Habermas etc., and their proposed reforms, to promote an egalitarian social order within the scope of markets. It critiques breezily even those models but it does not round off the argument with some explanation of what an egalitarian system would look like.

By and large, the motivation of this paper, to raise questions about the society that is being promoted through current economic paradigm, is laudable. It is searching for an alternative social order where markets could be brought under the rubric of a moral vision. Yet this search is confined to the narrow territory of the new left theories. Sen, Gilbraith or Illich, for example, have ideas that suggest a moral discipline for the global market, whose laissez-faire includes freedom to speculate without restraints.

The paper certainly calls for not surrendering to the vulgar utilitarianism. It raises the age-old issue of individualism versus community. Yet it is also locked inside the box it builds. Is the economy primarily a matter of trade, consumption, 
distribution and production? Is egalitarian social order realisable regardless of cultural, demographic, religious and technological differences among societies? What about environmental constraints? The paper does not give even a nod to these forces that shape both economy and society.

This paper is densely packed with premises, allusions and divergences. In attempting to draw together various old and new left-theoretical strands, the paper becomes one long discursive statement with many loose ends. It could have been more focussed by not attempting to touch upon every major proposition and presumption of the current economic discourse.

Queen's University,

Mohammad A. Qadeer

Canada. 